\title{
Structure-forming processes of cement composites, modified by sucrose additions
}

\section{Процессы структурообразования цементных композиций, модифицированных добавками сахарозы}

\author{
T.S. Shepelenko, \\ U.S. Sarkisov, \\ N.P. Gorlenko, \\ N.A. Tsvetkov, \\ O.A. Zubkova, \\ Tomsk State University of Architecture and \\ Building, Tomsk, Russia
}

Key words: cement; sucrose; products of sucrose corrosion of cement; addition agent; density

\author{
Канд. хим. наук, доцент Т.С. Шепеленко, \\ д-р техн. наук, профессор Ю.С. Саркисов, \\ д-р техн. наук, профессор Н.П. Горленко, \\ д-р техн. наук, профессор Н.А. Цветков, \\ канд. техн. наук, доцент О.А. Зубкова, \\ Томский государственный архитектурно- \\ строительный университет, г. Томск, Россия
}

Ключевые слова: цемент, сахароза, продукты сахарной коррозии цемента, добавка, прочность

\begin{abstract}
The effect of sucrose on the kinetics of cement hardening has been studied. The study was carried out in two comparative ways, one of which had the organic modifier introduced into cement as gauging liquid ("water $-2 \%$ sucrose solution"), the other - as suspensions "cement - water $-2 \%$ sucrose solution". The products of sucrose corrosion, synthesized in suspensions, were used as addition agents in the "cement - water" system. Suspension-based approach is interesting because of cement modification by introducing the corrosion products of the same cement, which provides setting acceleration and higher composite density. The structurization role of addition agents, containing products of sucrose corrosion of cement, is provided by synergetic influence of several factors: intensive growth of ettringite crystal nuclei - the main reinforcement component of a cement system, reduction of $\mathrm{Ca}(\mathrm{OH}) 2$ in solid phase of a rock, CSH-gel densifying and plasticizing. The use of sucrose as gauging liquid results in adverse effect for isolation of cement particles by adsorption layers, impeding the hydration, growth and possible coalescence of crystal - the destructurization of the setting system: the rocks, available from cement gauging with $2 \%$ sucrose solution were not set during the whole trial period. The results were interpreted by means of physic-chemical approaches: X-ray phase analysis, IR-spectroscopy, differential thermal analysis.
\end{abstract}

Аннотация. Изучено влияние сахарозы на кинетику твердения цемента. Исследование проведено в двух сравнительных вариантах, в одном из которых органический модификатор вводился в цемент в качестве жидкости затворения («вода-2\%-й раствор сахарозы»), в другом - в виде суспензий «цемент-вода-2\%-й раствор сахарозы». Продукты сахарной коррозии, синтезированные в суспензиях, применялись как добавки в систему «цемент-вода». Научный подход, основанный на использовании суспензий интересен тем, что цемент модифицируется введением продуктов коррозии этого же цемента и обеспечивает значительное ускорение схватывания и увеличение прочности композитов. Структурообразующая роль добавок, содержащих продукты сахарной коррозии цемента, обеспечивается благодаря синергетическому влиянию нескольких факторов: интенсивному росту зародышей кристаллов эттрингита - главного армирующего компонента цементной системы, уменьшению количества $\mathrm{Ca}(\mathrm{OH}) 2$ в твердой фазе камня, уплотнению CSH-геля и пластифицирующему действию. Применение сахарозы в качестве жидкости затворения приводит к отрицательному эфффекту изолирования частиц цемента адсорбционными оболочками, затрудняющими гидратацию, рост и возможность срастания кристаллов - наблюдается деструктуризация вяжущей системы: камни, полученные затворением цемента 2\%-м раствором сахарозы, не обнаружили схватывания в течение всего испытательного срока. Интерпретация результатов проведена с помощью физико-химических методов: РФА, ИКспектроскопии, ДТА.

Шепеленко Т.С., Саркисов Ю.С., Горленко Н. П., Цветков Н.А., Зубкова О.А. Процессы структурообразования цементных композиций, модифицированных добавками сахарозы // Инженерно-строительный журнал. 2016. № 6(66). С. 3-11. 


\section{Introduction}

Cement concrete is the main construction material in the world, therefore modification of its properties is under constant consideration of both Russian and foreign scientists. Cement is modified in the first place, as it is the binding agent that specifies the technological and operational features of concrete mixtures. P.-C. Aitchin, the author of HPC (High Performance Concrete) conception - provided rationalization for functional unity of cement and concrete, gaining density with effective addition agents [1]. In 2014 Russia produced 68424 ths. tons of cement, $48 \%$ of which is Portland cement with addition agents [2]. A particular value is assigned to organomineral addition agents, effecting rheological and physic-mechanical properties of cement and concrete [3-7].

In [8] it is shown that structurization processes of cement systems are regulated by introducing sucrose-containing addition agents. The influence of organic modifier upon kinetics of binding agent hardening has been studied in two comparative ways, one of which had the sucrose introduced into cement as a "water-sucrose solution" gauging liquid, the other - as "cement-water-sucrose" suspensions ("CWS"). Sucrose solutions, aggressive to cement, worked as a corrosive environment. The products of corrosion, synthesized in suspensions, were used as addition agents in the "cement-water" system, similarly to [9]. Depending on means of sucrose introduction, solution concentration and the quantity of addition agent the modification result varies from no setting of cement paste at all to sufficient acceleration of setting and hardening of cement composite materials.

The present work attempts to explain and prove the results of [8] on the example of modified samples MS2-0.1 and MS2, which have the polar opposite compression resistance values (Table 1). The comparison is interesting because of the same concentration of organic modifier in both instances $-2 \%$, but different means of sucrose introduction. Thus, rock MS2-0.1 was produced by introduction of an agent into cement paste, which was synthesized in "cement-water- $2 \%$ sucrose solution" suspension ( $\mathrm{M}$ - modified sample; 2 - concentration of sucrose solution, \%; 0.1 - amount of addition agent, wt. \%). MS2-0.1 during the whole period of hardening is distinguished by considerable increase in density compared to plain cement rock (PCR). The rock MS2, produced by gauging of the binding agent with $2 \%$ solution of sucrose, was not set throughout the whole trial period.

\section{Methods}

Plain cement rocks and modified cement rocks (MCR) were produced of topkinsky cement of PC400 D20 brand, shaped as cubes measuring $2 \mathrm{~cm}$ on edge, within normal hardening conditions; water-cement ratio is 0,34 .

MCR were produced in the following ways:

- MS2 was produced by means of gauging the base cement with $2 \%$ sucrose solution;

- MS2-0.1 was produced by means of introducing the "CWS" addition agent into the "cementwater" system in proportion $0.1 \%$ to the mass of the dry cement.

The "CWS" addition agent was synthesized through the following procedure:

1. A sample of the base gauging liquid was matured in a $2 \%$ sucrose solution in liquid/solid proportion 1:5 for 24 hours after thorough mixing of the suspension produced;

2. After the exposure period the solid and liquid parts of the suspension were separated by means of 2-hour filtering;

3. The solid residue was transferred quantitatively from the paper filter onto the Petri dish, stirred thoroughly, distributed evenly with a spreading rod, and dried in the air for 3 hours;

4. Thus prepared addition agent was ground in a porcelain mortar, passed through the strainer 008 according to the National State Standard 6613 and dried in a baker until it reached a constant weight at the temperature of $(110 \pm 5)^{\circ} \mathrm{C}$ according to the National State Standard 5382-91.

Table 1 shows the means of modifying the cement systems, as well as the compression resistance values $(\mathrm{R}, \mathrm{MPa})$ and density growth of MS2-0.1 compared to $\mathrm{PCR}(\Delta R, \%)$.

Compression resistance values of the rocks in the set terms of cement hardening (1-3-7-28) were determined following 6 separate measurements of every test point. The average density was calculated on the basis of three closest values, providing a margin of error not more than $5.6 \%$.

Shepelenko T.S., Sarkisov U.S., Gorlenko N.P., Tsvetkov N.A., Zubkova O.A. Structure-forming processes of cement composites, modified by sucrose additions. Magazine of Civil Engineering. 2016. No. 6. Pp. 3-11. doi: 10.5862/MCE.66.1 
Table 1 PCR and MCR specification

\begin{tabular}{|c|c|c|c|c|c|c|}
\hline \multirow{2}{*}{ CR } & \multirow{2}{*}{ Composition of CR } & \multicolumn{4}{|c|}{ Period of hardening, days } \\
\cline { 3 - 6 } & & 1 & 3 & 7 & 28 \\
\cline { 3 - 6 } & & \multicolumn{4}{|c|}{$R, \mathrm{Mpa} / \Delta R$ (versus $\mathrm{PCR}$ ), \% } \\
\hline PCR & (cement $\left.+\mathrm{H}_{2} \mathrm{O}\right)$ & 6.6 & 21.1 & 38.9 & 46.2 \\
\hline MS2-0.1 & (cement $\left.+\mathrm{H}_{2} \mathrm{O}\right)+$ addition agent "CWS" & $\frac{13.2}{100}$ & $\frac{25.7}{22}$ & $\frac{42.0}{8}$ & $\frac{61.9}{34}$ \\
\hline MS2 & $\begin{array}{c}\text { (cement }+2 \% \\
\text { sucrose solution) }\end{array}$ & - & - & - & - \\
\hline
\end{tabular}

The physiochemical analysis was carried out on the 28-day samples. The rocks were prepared for testing immediately after the density test. The samples, broken by the press, were ground in a planetary mill MP/0.5-4. The dispersion degree was checked by the powder measuring machine PSH-10a up to the specific surface value of $200 \mathrm{~m}^{2} / \mathrm{kg}$. There have been no measures taken to stop the hydration processes, as the period of time from the grade strength evaluation to the physiochemical analysis lasted not more than 2 hours for all the cement systems under consideration.

Table 2 shows the results of $X$-ray phase analysis. Figure 1 shows IR-spectra of the samples in question, Figure 2 - the results of differential thermal analysis.

IR-specters of the samples were registered with Fourier spectrometer Varian Excalibur HE 3600 within the frequency range $400-4000 \mathrm{~cm}^{-1}$; quality of neoformations composition was measured by X-ray diffraction meter of Shimadzu XRD-7000 with copper anode in range 5-90 deg. Differential thermal analysis was carried out by means of derivatograph NETZSCH STA 449 F3A-0010-M.

\section{Results and Discussion}

X-ray of MS2, produced by means of gauging a binding agent with $2 \%$ sucrose solution, shows that the reflex intensity of $\mathrm{C}_{3} \mathrm{~S}$ on $2 \theta$ scale at angles $29.280^{\circ}$ and $34.155^{\circ}$ versus unhydrated cement is only $5 \%$ and $8 \%$ lower respectively, of $\mathrm{C}_{2} \mathrm{~S}(32.172 \%)-20 \%$ lower (Table 2$)$.

IR-specter MS2 has the typical for unhydrated cement adsorption bands -920 and $516 \mathrm{~cm}^{-1}$ (stretching and deformation vibrations of $\mathrm{Si}-\mathrm{O}-\mathrm{Ca}$ ) - preserved and highly intensive (Figure 1). Given results are proved by reduction of portlandite reflection height in XPA patterns of MS2 versus PCR: 58 to $100 \%$ in the most important reflexes of this phase (Table 2).

According to DTA dehydration endoeffect area of $\mathrm{Ca}(\mathrm{OH})_{2}$ at $451^{\circ} \mathrm{C}$ on the MS2 thermograph is 4 times reduced versus PCR (Figure 2); adsorption in the IR-specter area with $3640 \mathrm{~cm}^{-1}$ max is also reduced. Low-level consumption of $\mathrm{C}_{3} \mathrm{~S}$ и $\mathrm{C}_{2} \mathrm{~S}$ and sharp reduction of portlandite quantity show that the use of sucrose as gauging liquid suppresses the hydration of cement silicate phases, similarly to [10-12].

Hydration of $\mathrm{C}_{3} \mathrm{~A}$ и $\mathrm{C}_{4} \mathrm{AF}$ in MS2 is hindered as well - that is implied by 3 of 4 adsorption bands of unhydrated cement preserved in IR-specter in the area $600-700 \mathrm{~cm}^{-1}$ (deformation vibrations of $\left(\mathrm{AlO}_{4}\right)^{-}$ tetrahedral in aluminates and alumoferrites, with stretching vibrations $1000-1150 \mathrm{~cm}^{-1}$ ). The authors [10-12] also registered the "aluminates accumulation" in cement composites, modified with sucrose.

Typical for MS2 is exothermic effect, peaking in $333.7^{\circ} \mathrm{C}$ (Figure 2), corresponding to oxidation of organic compositions, allegedly antacidins $[11,13]$ - products of sucrose reaction to $\mathrm{Ca}(\mathrm{OH})_{2}$.

It is noted in reference literature that small additions of sucrose slow down the hydration and hardening of cement. Sucrose, with the properties of hydrophilic SAS, peptizes cement particles and heightens early solubility of a binding agent. However the following "adsorption of sucrose on the surfaces of initial and metastable hydrate phases, as well as formation and adsorption of complex composites" [14] contributes to formation of membranes, screening the cement nuclei and hindering the hydration, growth and possible coalescence of crystals. Modifying effect of sucrose works on both aluminic and silicate phases of cement and comes from the capacity of $\mathrm{OH}$-groups of organic addition agent to form hydrogen-bonds [7, 10-19]. Primary stage of $\mathrm{C}_{3} \mathrm{~A}$ hydration is accelerated due to aluminates involved in complex formation. The following slowdown of hydration is determined by hexagonal phases stabilization and hindering of their transformation into cubic phase by means of Шепеленко Т.С., Саркисов Ю.С., Горленко Н. П., Цветков Н.А., Зубкова О.А. Процессы структурообразования цементных композиций, модифицированных добавками сахарозы // Инженерно-строительный журнал. 2016. № 6(66). С. 3-11. 
sucrose adsorption on the hydrate surfaces and formation of protective membranes. Data concerning surface complexes with hexagonal phases is obtained by means of DTA [14].

Table 2 X-ray phase analysis results

\begin{tabular}{|c|c|c|c|c|}
\hline \multicolumn{5}{|c|}{$\begin{array}{l}\text { Reflex intensity of primary crystalline phases of } \\
\text { PCR and MCR versus unhydrated cement, \% }\end{array}$} \\
\hline Phases & $2 \theta, 0$ & PCR & MS2 & MS2-0.1 \\
\hline \multirow{2}{*}{$\mathrm{C}_{3} \mathrm{~S}$} & 34.155 & -36.0 & -8.0 & -32.0 \\
\hline & 29.280 & -47.4 & -5.3 & -21.1 \\
\hline $\mathrm{C}_{2} \mathrm{~S}$ & 32.172 & -54.2 & -20.8 & -25.0 \\
\hline \multicolumn{5}{|c|}{$\begin{array}{c}\text { Reflex intensity of new crystalline phases of MCR } \\
\text { versus PCR, \% }\end{array}$} \\
\hline Phases & $2 \theta, 0$ & MS2 & & MS2-0.1 \\
\hline \multirow{3}{*}{ Ettringite } & 9.016 & \multirow{3}{*}{ PCR level } & & +40 \\
\hline & 15.530 & & & +67 \\
\hline & 22.962 & & & +25 \\
\hline \multirow{3}{*}{ Portlandite } & 17.978 & -73 & & -50 \\
\hline & 34.061 & -58 & & -37 \\
\hline & 50.976 & -100 & & -33 \\
\hline
\end{tabular}

Y.E. Young $[20,21]$ stated that sucrose molecules change the morphology of ettringite and stabilize it, which conforms to ideas of sugars slowing the transformation of hydrated calcium sulfoaluminate into monosulfoaluminate [14, 22].

The slowdown effect of organic modifier was related to stabilization of the surface complex, including surfaces of alite hydration products $-\mathrm{CH}$ and $\mathrm{CSH}$, sucrose and water, while complex stabilization is the higher, the higher is sucrose concentration in gauging liquid [12, 14, 15, 23]. It has been discovered that sucrose adsorption changes the $\mathrm{CSH}$-phase sufficiently and prevents its nucleation. $\mathrm{X}$-ray phase analysis has proved that introduction of wt. $0.3 \%$ sucrose causes the deformation of CSH structure. Disaccaride molecules are adsorbed horizontally on the surfaces of hydrosilicates, creating steric hindrance during their crystallization and raising inhomogenity of calcium hydrosulfate phases [10].

It is noted that the dosage of sucrose higher than $0.7 \mathrm{wt}$ \% [10] has "catastrophic effect on cement systems" due to higher role of adsorption membranes [10,11,13], hindering the intensity of hydrolized hydration. In [3] it was shown that with use of $1 \%$ sucrose solution as gauging liquid the binding agent does not set during 7 days; at the $28^{\text {th }}$ day modified cement rocks show compression strength of $2.6 \mathrm{Mpa}$. Raising sucrose concentration in gauging liquid to $2 \%$ spikes the negative effect of disaccharide: cement system does not set during 28 days (Table 1 ).

In [8] it was confirmed that aggressive effect of sucrose is diminished if the means of introduction into "cement-water" system is changed: use of sucrose in addition agent, synthesized in "CWS" suspension, raises the 1-day density of modified rock MS2-0.1 to $100 \%$ versus PCR, 28-day density - to $34 \%$ (Table 1).

XRD results show that the reflex intensity of hydrated calcium sulfoaluminate in MS2-0.1 at reflex angles $22.962{ }^{\circ}, 9.016^{\circ}$ и $15.530^{\circ}$ on $2 \theta$ scale versus PCR is higher in $25 \%, 40 \%$ and $67 \%$ accordingly (Table 2). That may be considered a progressive factor, responsible for intensive

Shepelenko T.S., Sarkisov U.S., Gorlenko N.P., Tsvetkov N.A., Zubkova O.A. Structure-forming processes of cement composites, modified by sucrose additions. Magazine of Civil Engineering. 2016. No. 6. Pp. 3-11. 
development of reinforcement net of structural skeleton, forming the density of cement composite [24, 25].

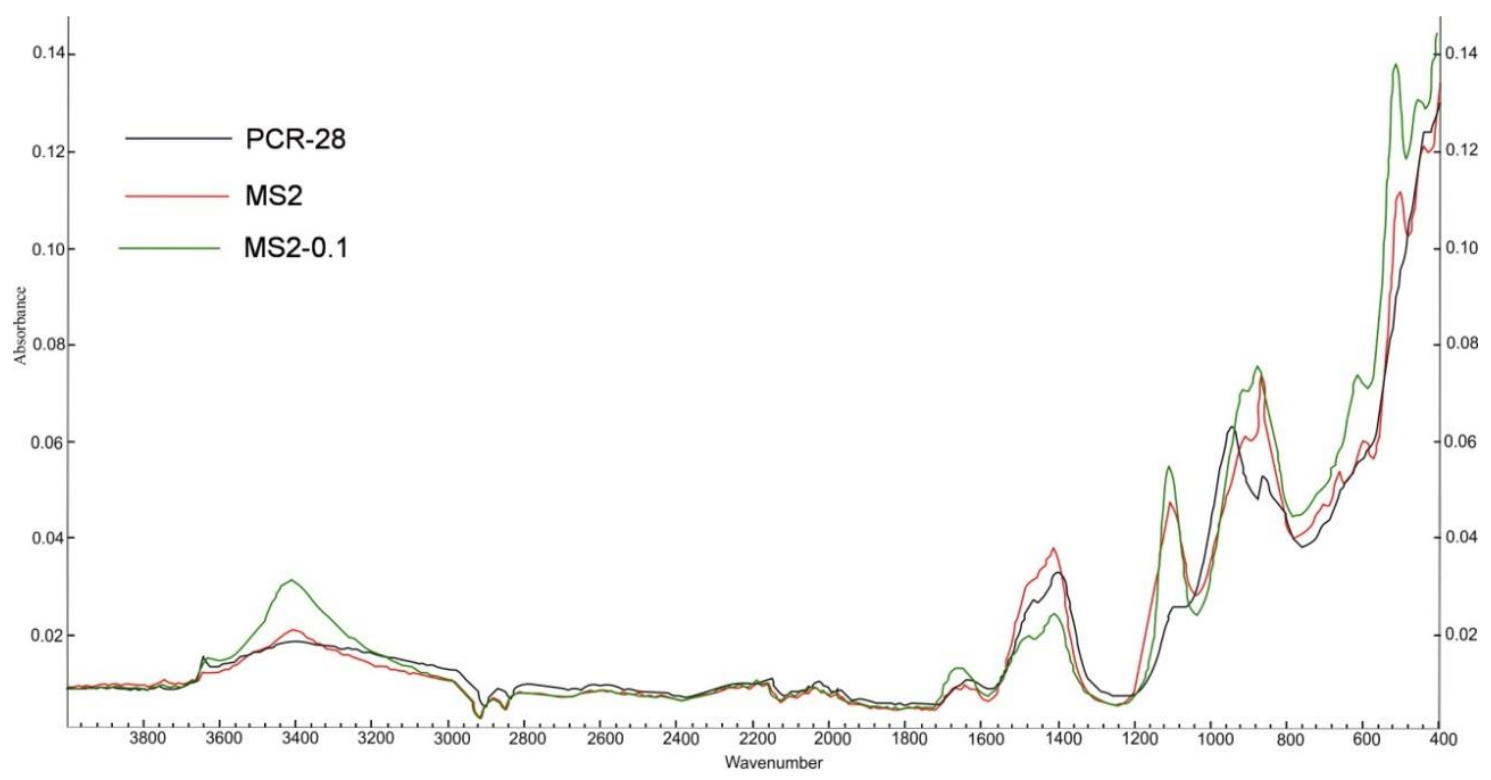

Figure 1. IR-spectra of PCR and modified samples

One more key factor, contributing to the development of more homogeneous and dense structure of MS2-0.1 rock versus PCR is a sufficient reduction of portlandite amount - the less stable component of a cement rock. The reduction of reflex intensity in the crucial reflexes of the given crystal line on $2 \theta$ scale is $33 \%(50.976 \%), 37 \%\left(3.061^{\circ}\right)$ and $50 \%(17.978 \%)$.

IR-specter of MS2-0.1 is specified by sufficiently higher adsorption in every area, typical for cement systems, except for maximum $1475 \mathrm{~cm}^{-1}$ band, responsible for water molecules vibrations in interlayer structure of calcium hydrosulphates. Higher adsorption at $3411 \mathrm{~cm}^{-1}$ is explained by vibrations of water molecules in crystallohydrates, as well as $\mathrm{OH}$-groups of sucrose $\left(3150-3600 \mathrm{~cm}^{-1}\right)$. More remarkable changes take place in the area with the peak of $1080 \mathrm{~cm}^{-1}$, responsible for the formation of lowly crystallized phases of tobleromorite-like structured calcium hydrosulphate: if considering PCR a dependent blurred shoulder peak to $953 \mathrm{~cm}^{-1}$ band is observed, MS2-0.1 specter shows a sharp peak, higher in $112 \%$ (Pic. 1). In the wavenumbers interval $600-700 \mathrm{~cm}^{-1}$ specter MS2-0.1 has only one peak with $613 \mathrm{~cm}^{-1}$ left out of the adsorption bands of unhydrated cement $\left(596,614,677\right.$, and $\left.727 \mathrm{~cm}^{-1}\right)$, which proves the hydration of $\mathrm{C}_{3} \mathrm{~A}$ and $\mathrm{C}_{4} \mathrm{~F}$, different from $\mathrm{MS} 2$, modified by sucrose solution.

It is known, that up to $70 \%$ of solid phase of completely hydrated cement consists of CSH-gel, with high density of adhesive bonding with other hydration products, which specifies crucial operative features of cement rock: density, volume stability, permeability, plastic flow and shrinking properties. Contemporary approaches of colloid system studies describe CSH-phase as a cluster of particles about 5 $\mathrm{nm}$, on the higher level grouping into units of 30-100 nm. Every base particle consists of united submicrocrystals of banded structure [26-30]. It is considered, that "real CSH is a banded hybrid of natural equivalent minerals $-1.4 \mathrm{~nm}$ of tobermorite $\mathrm{Ca}_{4} \mathrm{Si}_{5} \mathrm{O}_{6} \cdot 2.7 \mathrm{H}_{2} \mathrm{O}$ and jennite $\mathrm{Ca}_{9} \mathrm{Si}_{6} \mathrm{O}_{18} \cdot 6.8 \mathrm{H}_{2} \mathrm{O}$ " $[28,31]$.

The quality of gel - density, homogeneity, adaptability, adhesion capability - is specified by the quantity and distribution properties of water in calcium hydrosulphate. A significant amount of water is concentrated "between interlayer sheets, dividing them slightly wider than one water molecule". Quantum-mechanic calculations proved the energy of binding superplastifier C3 sulpho-group with alite to be $540 \mathrm{~kJ} / \mathrm{mol}$, which is 2.8 times higher than similar value for water molecule $(190 \mathrm{~kJ} / \mathrm{mol})$. That means that C-3 molecules are stronger bound to alite surface and can push water out of interlayer space, contributing to binding of particles or layers. Every monomerous link of C-3 supplaces up to $30 \mathrm{H}_{2} \mathrm{O}$ molecules, providing the plasticization of the cement system [32].

Hardening effect of plasticizers on the structure of a binding agent in concrete, apart from plasticization procedure, is shown in their influence on the dispersive-crystallite structure of a cement rock. Real crystal is a coagulate of smaller irregular-shaped crystals - microcrystals (grains). A grain is

Шепеленко Т.С., Саркисов Ю.С., Горленко Н. П., Цветков Н.А., Зубкова О.А. Процессы структурообразования цементных композиций, модифицированных добавками сахарозы // Инженерно-строительный журнал. 2016. № 6(66). С. 3-11. 
comprised of mosaic blocks, which have their atomic levels, wedged from one another at a small angle of several minutes [33]. It is proved that $\mathrm{C}_{3} \mathrm{~S}$ hydration with $1 \%$ (wt.) $\mathrm{C}-3$ is followed by higher amount of $\mathrm{CSH}$ (I) and lower amount of CSH (II); the size of mosaic blocks is reduced from 20-33 to 15-17 nm. Such changes lead to sufficient raise in hardening structure density.

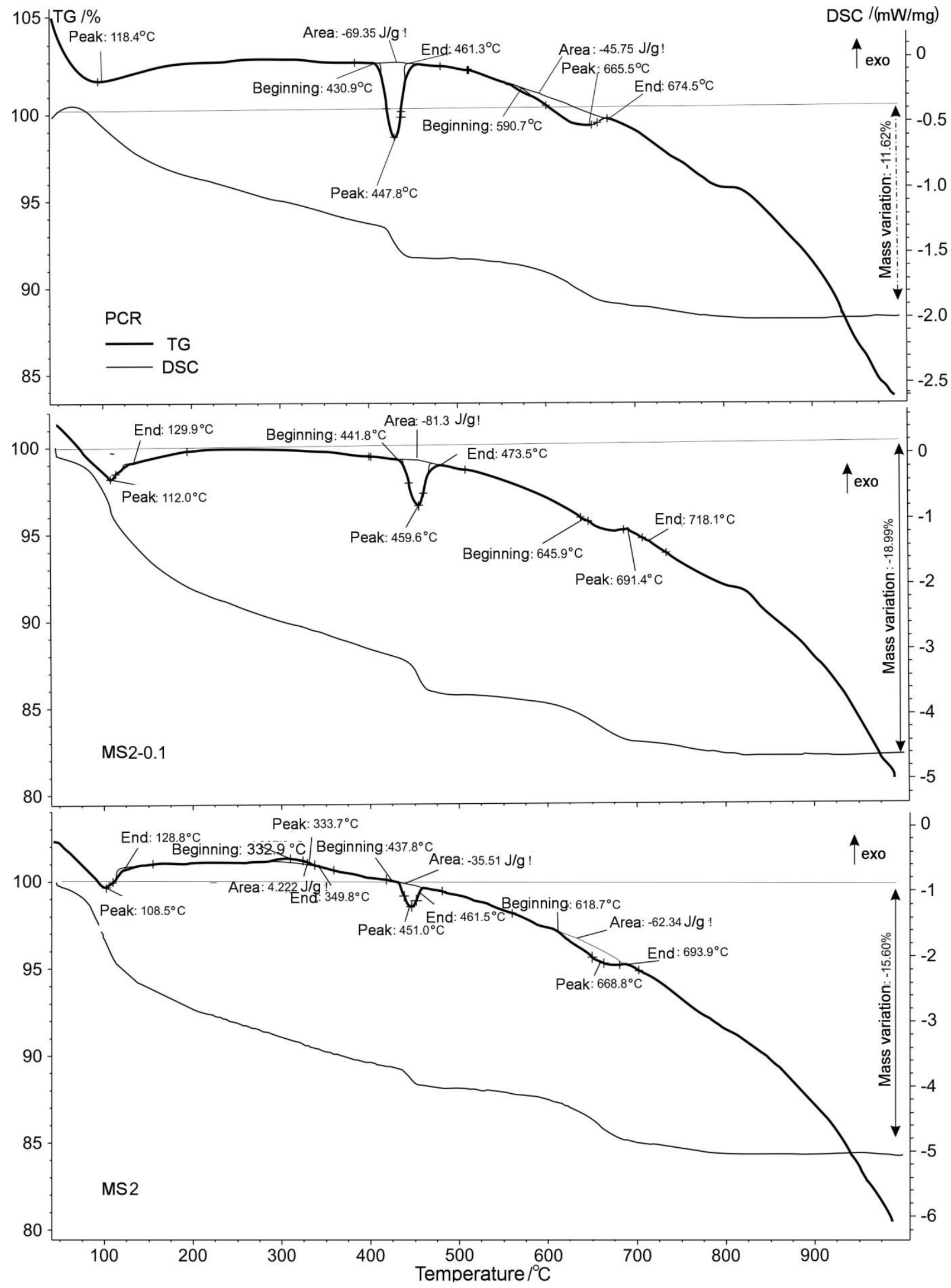

Figure 2. Derivatograms of PCR and modified samples

Shepelenko T.S., Sarkisov U.S., Gorlenko N.P., Tsvetkov N.A., Zubkova O.A. Structure-forming processes of cement composites, modified by sucrose additions. Magazine of Civil Engineering. 2016. No. 6. Pp. 3-11. 
The effect of sucrose on cement as a plasticizing agent, while shown sufficiently lower due to lesser size of disaccharide molecules and lower amount of functional groups, in general is similar to C-3 effect. It is circumstantially proved by abovementioned reduction of adsorption intensity in IR-specter of the MS2-0.1 rock in $1475 \mathrm{~cm}^{-1}$ area, specifying the vibrations of interlayer water $-42 \%$ versus PCR and $58 \%$ versus MS2. However the discovered phenomenon calls for more solid experimental evidence.

One can suppose that the products of sucrose corrosion of cement, synthesized in "CWS" suspensions - microcrystals of ettringite, other crystal phases and neoformations of organomineral nature (hybrid composites, cognate to both cement and sucrose), being introduced into "water-cement" system work as active centers of structure development. The addition agent, enriched with cement corrosion products, according to Le Chatelier principle, inhibits the activity of early destruction of clinker minerals and catalyses the development of skeletal matrix of a cement rock, realizing the known principle of self-reinforcing [24], also positively affecting the properties of cement gel and heightening its density.

\section{Conclusions}

The conducted studies and interpretation of the results, offered in the article, allow to draw the following conclusions:

1. Acceleration of setting and hardening of the cement composite MS2-0.1 is realized due to synergic effect of several factors: intensive growth of ettringite crystal nuclei - the main reinforcing component of the cement system, reduction of $\mathrm{Ca}(\mathrm{OH})_{2}$ amount in the solid phase of a cement rock, densifying of $\mathrm{CSH}$-gel and plasticizing effect.

2. The use of sucrose as gauging liquid causes the adverse effect: cement particles are isolated by adsorption membranes, hydration processes are hindered, destructurization of the binding system takes place.

Thus the addition of "CWS" suspension carries out the structurization function onto the "watercement" system and can be recommended to improve the operational properties of cement composites.

\section{References}

1. Aitchin P.-C. Cements of yesterday and today: concrete of tomorrow. Cement and concrete research. 2000. Vol. 3. No. 9. Pp. 1349-1359.

2. Zharko V.I., Guz' V.A., Afanas'ev A.F. Proizvodstvo i rynok tsementa v Rossii v 2014 godu [Prodaction and market of cement in Russia 2014]. Tsement i ego primenenie. 2015. No. 1. Pp. 18-21. (rus)

3. Gussoni M., Greco F., Bonazzi F., et al. 1H NMR spin-spin relaxation and imaging in porous systems: an application to the morphological study of white portland cement in the presence of organic. Magn Reson Imag. 2004. No. 22(6). Pp. 877-879.

4. Kuo W.-Y., Huang J.-S., Lin C.-H. Effects of organomodified montmorillonite on strengths and permeability of cement mortars. Cem. Concr. Res. 2006. Vol. 36. No. 5. Pp. 886-895.

5. Abalaka A.E. Effects of sugar on physical properties of ordinary portland cement paste and concrete. $A U$ J. T. 2011. Vol. 14. No. 3. Pp. 225-228.

6. Tkach R.V., Rakhimov M.A., Toimbaeva V.M., Rakhimova V.M. Vliyanie organomineral'nogo modifikatora na fizikomekhanicheskie i deformativnye svoistva betona [The effect of the organic-mineral modifier on physical and mechanical deformation properties of the concrete]. Fundamental'nye issledovaniya. 2012. No. 3. Pp. 428-431. (rus)

7. Shoshin E.A., Bylinkina N.N. Uglevody, kak elementy upravleniya strukturoi nanofazy tsementnogo kamnya [Carbohydrates as a way to control the structure of cement stone nanofazy]. Vestnik BGTU im. V.G. Shukhova. 2015. No. 5. Pp. 53-57. (rus)

8. Shepelenko T., Sarkisov Y., Afanasyev D., Akimova N. Regulatorsh ardening, containing products of sugar. Cambridge Journal of Education and Science. 2015. No. 2(14). Pp. 585-592.

Шепеленко Т.С., Саркисов Ю.С., Горленко структурообразования цементных композиций, Инженерно-строительный журнал. 2016. № 6(66). С. 3-11.

\section{Литература}

1. Aitchin P.-C. Cements of yesterday and today: concrete of tomorrow // Cement and concrete research. 2000. Vol. 3. № 9. Рp. 1349-1359.

2. Жарко В.И., Гузь В.А., Афанасьев А.Ф. Производство и рынок цемента в России в 2014 году // Цемент и его применение. 2015. № 1. С. 18-21.

3. Gussoni M., Greco F., Bonazzi F., et al. 1H NMR spin-spin relaxation and imaging in porous systems: an application to the morphological study of white portland cement in the presence of organic // Magn. Reson. Imag. 2004. № 22(6). Pp. 877-879.

4. Kuo W.-Y., Huang J.-S., Lin C.-H. Effects of organomodified montmorillonite on strengths and permeability of cement mortars // Cem. Concr. Res. 2006. Vol. 36. № 5. Pp. 886-895.

5. Abalaka A.E. Effects of sugar on physical properties of ordinary portland cement paste and concrete // AU J. T. 2011. Vol. 14. № 3. Pp. 225-228.

6. Ткач Р.В., Рахимов М.А., Тоимбаева В.М., Рахимова В.М. Влияние органоминерального модификатора на физико-механические и деформативные свойства бетона // Фундаментальные исследования. 2012. № 3. C. 428-431.

7. Шошин Е.А., Былинкина Н.Н. Углеводы, как элементы управления структурой нанофазы цементного камня // Вестник БГТУ им. В.Г. Шухова. 2015. № 5. С. 53-57.

8. Shepelenko T., Sarkisov Y., Afanasyev D., Akimova N. Regulatorsh ardening, containing products of sugar // Cambridge Journal of Education and Science. 2015. № 2(14). Pp. 585-592.

9. Shepelenko T.S., Sarkisov Y.S. Corrosion products of cement, as effective modifiers increase the strength of cement systems // Australian Journal of Scientific Research. 2014. № 1(5). Pp. 374-381.

Н. П., Цветков Н.А., Зубкова О.А. Процессы модифицированных добавками сахарозы // мод 
9. Shepelenko T.S., Sarkisov Y.S. Corrosion products of cement, as effective modifiers increase the strength of cement systems. Australian Journal of Scientific Research. 2014. No. 1(5). Pp. 374-381.

10. Tarakanov O.V.Tsementnye materialy $s$ dobavkami uglevodov [Cement materials with carbohydrate addives] Penza: PGASA, 2003. 166 p. (rus)

11. Ivashchenko Yu.G., Kozlov N.A. Issledovanie vliyaniya organomineral'nogo modifikatora na protsessy strukturoobrazovaniya i kinetiku nabora prochnosti tsementnykh kompozitsii [Research of influence of organic modifier on the processes of structure and kinetics of strength development in cement composites]. Vestnik BGTU im. V.G. Shukhova. Seriya: Stroitel'stvo i arkhitektura. 2011. No. 4(49). Pp. 15-18. (rus)

12. Smith B.J., Rawal A., Funkhouser G.P., et al. Origins of saccharide-dependent hydration at aluminate, silicate and aluminosilicate surfaces. PNAS. 2011. Vol. 108. No. 22 Pp. 8949-8954.

13. Kireev Yu.L., Nesterova N.N., Luchinina I.G. O vzaimodeistvii mineralov portlandtsementnogo klinkera $s$ rastvorom sakhara [On the interaction of Portland cement clincer minerals with a sugar solution]. Cement. 1999. No. 4. Pp. 19-21. (rus)

14. Ramachandran V.S., Fel'dman R.F., Kollepardi M. Dobavki $\checkmark$ beton: spravochnoe posobie [Additives in concrete: a handbook]. Moskva: Stroiizdat, 1988. 575 p.(rus)

15. Glekel' F.L., Kopp R. Z., Musaeva R. I. I dr. Zavisimost' effekta deistviya plastifikatora tsementnykh dispersii ot prirody gidratiruyushchikhsya faz [The dependence of effect of cement dispersions plasticizer on the nature of the hydrating phase]. J. of Applied Books. 1989. Vol. 62. No. 5. Pp. 1026-1028. (rus)

16. Thomas N.L., Birchall J.D. The retarding action of sugars on cement. Cement and Concrete Research. 1983. Vol. 13. No. 6. Pp. 830-842.

17. Juenger M.C. New insights into the effect of sugar on the hydration and microstructure of cement pastes. Cement and Concrete Research. 2002. Vol. 32. No. 3. Pp. 393-399.

18. Ivashchenko Yu.G. Modifitsiruyushchee deistvie organiche skikh dobavok na tsementnye kompozitsionnye materialy [Modifying effect of organic additives on cement composites]. Vestnik SGTU. 2012. No. 4(68). Pp. 202-205. (rus)

19. Reschard A., Gorin A., Fredon E., et. al. Influence of polysaccharides on cement hydratation. Key Engineering Materials. 2004. Vol. 264. Rp. 2141-2144.

20. Young Y.E. Effect of organic compounds on the Interconversion of calcium Aluminate Hydrate. Hydratation of the Tricalcium Aluminate. J. of the American Ceramic Society. 1970. No. 53. Pp. 65-69.

21. Young Y.E. Reaction mechanism of Organic Admixtures with Hydrating Cement Compounds. Transportation Research Record. 1976. №. 564. Pp. 1-9.

22. Moore A. and Taylor H.F.W. Crystal structure of ettringite. Nature. 1968. Vol. 218. Pp. 1048-1049.

23. Shoshin Ye.A., Polyakov A.V., Burov A.M. Izmenenie nanostruktury model'noi silikatnoi sistemy $v$ usloviyakh posledovatel'nogo izmeneniya kontsentratsii sakharozy [Changes in the nanostructure of a model silicate system in terms of sequenial changes in the concentration of sucrose]. Vestnik BGTU im. V.G. Shukhova. 2016. No. 3. Pp. 23-30. (rus)

24. Timashev V.V., Sycheva I.I., Nikonova N.S. Struktura samoarmirovannogo tsementnogo kamnya. Izbrannye trudy. Sintez i gidratatsiya vyazhushchikh materialov [Structure of self-reinforced cement rock. Selected works. Synthesis and hydration of cementitious materials]. Moskva: Nauka, 1986. Pp. 390-400. (rus)

25. Chernyshov E.M., Korotkikh D.N. Nanofibrerein for cement
10. Тараканов О.В.Цементные материалы с добавками углеводов. Пенза: ПГАСА, 2003. 166 с.

11. Иващенко Ю.Г., Козлов Н.А. Исследование влияния органоминерального модификатора на процессы структурообразования и кинетику набора прочности цементных композиций // Вестник БГТУ им. В.Г. Шухова. Серия: Строительство и архитектура. 2011. № 4(49). C. $15-18$

12. Smith B.J., Rawal A., Funkhouser G.P., et al. Origins of saccharide-dependent hydration at aluminate, silicate and aluminosilicate surfaces // PNAS. 2011. Vol. 108. № 22. Pp. 8949-8954.

13. Киреев Ю.Л., Нестерова Н.Н., Лучинина И.Г. О взаимодействии минералов портландцементного клинкера с раствором сахара // Цемент. 1999. № 4. C. 19-21.

14. Рамачандран В.С., Фельдман Р.Ф., Коллепарди М. Добавки в бетон: справочное пособие. М.: Стройиздат, 1988. $575 \mathrm{c}$.

15. Глекель Ф.Л., Копп Р. З., Мусаева Р. И. И др. Зависимость эфффекта действия пластификатора цементных дисперсий от природы гидратирующихся фаз // Журнал прикладной химии. 1989. Vol. 62. № 5. C. $1026-1028$.

16. Thomas N.L., Birchall J.D. The retarding action of sugars on cement // Cement and Concrete Research. 1983. Vol. 13. № 6. Pp. 830-842.

17. Juenger M.C. New insights into the effect of sugar on the hydration and microstructure of cement pastes // Cement and Concrete Research. 2002. Vol. 32. № 3. Pp. 393-399.

18. Иващенко Ю.Г. Модифицирующее действие органических добавок на цементные композиционные материалы // Вестник СГТУ. 2012. № 4(68). С. 202-205.

19. Reschard A., Gorin A., Fredon E., et. al. Influence of polysaccharides on cement hydratation // Key Engineering Materials. 2004. Vol. 264. Pp. 2141-2144.

20. Young Y.E. Effect of organic compounds on the Interconversion of calcium Aluminate Hydrate. Hydratation of the Tricalcium Aluminate // J. of the American Ceramic Society. 1970. № 53. Pp. 65-69.

21. Young Y.E. Reaction mechanism of Organic Admixtures with Hydrating Cement Compounds // Transportation Research Record. 1976. № 564. Pp. 1-9.

22. Moore A. and Taylor H.F.W. Crystal structure of ettringite // Nature. 1968. Vol. 218. Pp. 1048-1049.

23. Шошин Е.А., Поляков А.В., Буров А.М. Изменение наноструктуры модельной силикатной системы В условиях последовательного изменения концентрации сахарозы // Вестник БГТУ им. В.Г. Шухова. 2016. № 3. C. $23-30$.

24. Тимашев В.В., Сычева И.И., Никонова Н.С. Структура самоармированного цементного камня. Избранные труды. Синтез и гидратация вяжущих материалов. М.: Наука, 1986. С. 390-400.

25. Chernyshov E.M., Korotkikh D.N. Nanofibrerein for cement of cement stone structures with help of crystals as a space of concrete fracture strength. // Scientific Israel Technological. 2009. Vol. 11. Pp. 23-28.

26. Manzano H., Agueva A., Dolado J.S. On the formation of cementitious C-S-H nanoparticles // J. Comp.-Aided Mater. Design. 2007. № 14. Pp. 45-51.

27. Richardson I.G. The calcium silicate hydrates // Cement and concrete research. 2008. Vol. 38. Pp. 137-158.

28. Pelleng R.J.-M. A realistic molecular model of cements hydrates // Proceedings of the national Academy of the Sciences. 2009. Vol. 106. № 38. Pp. 16102-16107.

29. Allen A.J., Tomas J.J. Analysis of C-S-H gel and cement paste by small-angle neutron scattering // Cem. Concr. Res. 2007. Vol. 37. № 3. Pp. 319-324.

Shepelenko T.S., Sarkisov U.S., Gorlenko N.P., Tsvetkov N.A., Zubkova O.A. Structure-forming processes of cement composites, modified by sucrose additions. Magazine of Civil Engineering. 2016. No. 6. Pp. 3-11. 
of cement stone structures with help of crystals as a space of concrete fracture strength. Scientific Israel Technological. 2009. Vol. 11. Pp. 23-28.

26. Manzano H., Agueva A., Dolado J.S. On the formation of cementitious C-S-H nanoparticles. J. Comp.-Aided Mater. Design. 2007. No. 14. Pp. 45-51.

27. Richardson I.G. The calcium silicate hydrates. Cement and concrete research. 2008. Vol. 38. Pp. 137-158.

28. Pelleng R.J.-M. A realistic molecular model of cements hydrates. Proceedings of the national Academy of the Sciences. 2009. Vol. 106. No. 38. Rp. 16102-16107.

29. Allen A.J., Tomas J.J. Analysis of C-S-H gel and cement paste by small-angle neutron scattering. Cem. Concr. Res. 2007. Vol. 37. No. 3. Pp. 319-324.

30. Beaudoin J.J., Drame H., Raki L. Alizadeh R. Formation and properties of C-S-H - HDTMA. J. Mater. Res. 2008. Vol. 23. No. 10. Pp. 2804-2815.

31. Bonaccorsi E., Merlino S., Taylor H.F.W. The crystal structure of jennite, $\mathrm{Ca}_{9} \mathrm{Si}_{6} \mathrm{O}_{18}(\mathrm{OH}) 6-8 \mathrm{H}_{2} \mathrm{O}$. Cem. Concr. Res. 2004. No. 34. Pp. 1481-1488.

32. Yuhnevsky P.I., Zelenkovskii V.M., Soldatov V.S. O modeli struktury gidrosilikatnogo gelya i vliyanii khimicheskikh dobavok-plastifikatorov. [On a model of the hydrosilicate gel structure and the effect of the chemical plasticizing additives]. Nauka - proizvodstvu. 2013. No.1. Pp. 25-29. (rus)

33. Yuhnevsky P.I., Zelenkovskii V.M., Soldatov V.S. Kvantovokhimicheskoe modelirovanie vzaimodeistviya polimetilennaftalinsul'fonatov natriya (dobavka C-3) S gidratirovannoi poverkhnost'yu alita $\mathrm{S}_{3} \mathrm{~S}$. [Quantumchemical modeling of the interaction of sodium polymethylenenaphtalenesulfonate (additive C-3) with a surface hydrated alite $\mathrm{C}_{3} \mathrm{~S}$ ]. Tekhnologiya betonov. 2010. No. 5-6. Pp. 31-33. (rus)

Tatiana Shepelenko,

+7(382)642445; shepta72@mail.ru

Yuri Sarkisov,

+7(3822)640907; sarkisov@tsuab.ru

Nicholas Gorlenko,

+7(3822)640907; Gorlen52@mail.ru

Nicholas Tsvetkov,

+7(3822)654281; nac.tsuab@yandex.ru

Olga Zubkova,

+7(3822)642445; zubkova0506@mail.ru
30. Beaudoin J.J., Drame H.,Raki L. Alizadeh R. Formation and properties of C-S-H - HDTMA // J. Mater. Res. 2008. Vol. 23. № 10. Pp. 2804-2815.

31. Bonaccorsi E., Merlino S., Taylor H.F.W. The crystal structure of jennite, Ca9Si6O18(OH)6-8H2O // Cem. Concr. Res. 2004. № 34. Рp. 1481-1488.

32. Юхневский П.И., Зеленковский В.М., Солдатов В.С. О модели структуры гидросиликатного геля и влиянии химических добавок-пластификаторов // Наука производству. 2013. № 1. С. 25-29.

33. Юхневский П.И., Зеленковский В.М., Солдатов В.С. Квантово-химическое моделирование взаимодействия полиметиленнафталинсульфонатов натрия (добавка С3) с гидратированной поверхностью алита $\mathrm{C}_{3} \mathrm{~S} / /$ Технология бетонов. 2010. № 5-6. С. 31-33.
Татьяна Станиславовна Шепеленко, +7(382)642445; эл. почma: shepta72@mail.ru

Юрий Сергеевич Саркисов, +7(3822)640907; эл. почта: sarkisov@tsuab.ru

Николай Петрович Горленко, +7(3822)640907; эл. почта: Gorlen52@mail.ru

Николай Александрович Цветков, $+7(3822) 654281$; эл. почта: nac.tsuab@yandex.ru

Ольга Александровна Зубкова, $+7(3822) 642445$ эл. почта: zubkova0506@mail.ru

(c) Shepelenko T.S., Sarkisov U.S., Gorlenko N.P., Tsvetkov N.A., Zubkova O.A., 2016

Шепеленко Т.С., Саркисов Ю.С., Горленко Н. П., Цветков Н.А., Зубкова О.А. Процессы структурообразования цементных композиций, модифицированных добавками сахарозы // Инженерно-строительный журнал. 2016. № 6(66). С. 3-11. 